ous bureaus of research, the suggestions made and conclusions reached should commend themselves to all interested in the public schools and in general government efficiency.

In general it may be said that the work shows what is being done, and what can and should be done, in the way of cooperation, to make the public schools more effective; and the subject is treated from every point of contact and viewed from every angle. In spite of the fact that perhaps $\$ 10,000,000$ are being spent annually by public and private agencies to supplement the work of public schools in the United States, which is more than the income from the Rockefeller and Carnegie foundations combined, yet the writer feels that the present activities do not meet the needs of the public schools, and the general apathy and lack of interest still presents a problem which is far from solved and in which, in many instances, but a poor beginning has been made-and indeed in thousands of instances not even a visible sign of a beginning. The solution of the public school problem, therefore, lies in effective outside coöperation, and this can only be brought about by a general awakening of the public conscience and applying the remedies already worked out in the more favored localities to the unenlightened communities. This can best be accomplished by central organizations which shall act as distributing agencies of information necessary to raise the general level of efficiency. But of course the real problem is essentially a local one and local interest must awake to meet the situation. This interest moreover must come from voluntary organizations and associations. Officials will be stimulated to do their full duty, school budgets will be increased to meet the proper needs, and an effective teaching staff will be secured only when the public has an honest-which is an intelligent--enthusiasm for the public schools.

With the general suggestions outlined in this work, the majority of students of social reform will agree. Efficiency in school administration as in other lines of government will only come when a vital contact between the agents of the people and the people themselves is effected, and this can only be brought about by voluntary action from the latter. This fact has been demonstrated by such organizations as the National Municipal League and the various municipal voters leagues. These organizations have done much to stimulate an honest and intelligent interest in politics and there is reason to believe that the various voluntary associations suggested here would do the same for the public schools. But they must be organized and unified under a more intelligent administration than is often the case at the present time. Minor criticisms may be urged against this volume. The facts are not always arrayed in the most logical manner and a certain carelessness and looseness of expression fails to drive home the conviction which the facts would really justify. Quotations are often made with no indication of the source, and frequent references to unfamiliar cities are made with no hint as to the name of the state in which they are located. There are numerous typographical errors-too numerous in fact to be pointed out-which perhaps may also account, in part at least, for the faulty punctuation frequently met with. But on the whole the work is a contribution to a much neglected field of civic life.

\section{Oberlin College.}

KarL F. Geiser.

The Conservation of the Chind. By Arthur Holmes, Assistant Director of the Psychological Clinic, University of - Pennsylvania. Philadelphia: J. B. Lippincott and Company, \$1.25.

How to tell when children are mentally, morally or physically defective; how to classify each child so as to secure for him the best individual care; how to conduct a psychological clinic in close 
coöperation with schools, charitable societies, hospitals and universities; how to give physical, pedagogical and psychophysical tests and interpret their resultsall this is told with a wealth of case detail in the Conservation of the Child.

Dr. Holmes' description of the routine procedure of the clinic, of what its physicians, psychologists and social workers do every day, his full presentation of Binet, laboratory and school book tests, and his historical summaries of interest in feeble-minded children, are primarily of value to the physician, psychologist and teacher of atypical children. For all teachers of normal children, for parents and social workers, the book includes many sign posts and danger warnings among its analyses of early symptoms of feeble-mindedness, and its constant references to the school problems of retardation and over-age.

Every city is in the midst of or must eventually go through the experience of coördinating the agencies, public and private, that are in touch with mentally abnormal children. Dr. Holmes has outlined a system of coöperation between these forces in Philadelphia through the clinic which aims to be a "a helpful coordinating, correlative agency among all societies and organizations aiming at the welfare of children."

Every one of the four thousand children brought to the clinic since 1896 received a thorough physical examination, and if adenoids or decayed teeth seemed the possible cause of backwardness or badness, these defects were remedied before the mental tests were made.

When a child is classified as corrigible or incorrigible and its treatment outlined by the examiner, he is not sent back to home and school to get along as best he can, but the necessary watching and special instruction are given either at the clinics' hospital school, in the child's home or in some institution. Each child receives the continuing service of a specially trained social worker, a friend till the last, which means permanent com- mitment to an institution, or maximum development of his powers.

For its record of a smoothly running organization, unique in this country, as well as for its suggestions to other cities, and to all people caring for feeble-minded children, the Conservation of the Child will be of lasting service.

William H. Allen.

New York City.

$\$$

Flies and Mosquitoes as Carriens of Drsease. By William Paul Gerhard, C.E. New York. Published by the author, Forty-second Street Building, 25 cents.

Dr. Gerhard is a well-known writer on public sanitation, and his works are usually full of valuable information. The pamphlet in question, including some 16 pages of text, bears inside as an apparent sub-title, "What farmers can do to assist in the campaign against flies and mosquitoes," and the paper is as a whole a reprint of an article written for The Country Gentleman several years ago.

Dr. Gerhard brings together a brief and rather capable summary of the flyfighting methods and the mosquito extermination practices so far developed and published. The pamphlet, as far as it goes, presents, therefore, important matter which it is well to have widely circulated.

Regret is felt, however, that Dr. Gerhard has not said anything new, and that in common with others who are dealing with the subject of fly-fighting particularly, he has "side-stepped" the suggestion of any practicable methods whereby the farmer may prevent the breeding of flies without destroying the value of horse manure. It is well enough of course, to suggest that horse manure should be promptly removed from city stables, or that it should be so treated as to prevent the breeding of flies. It is, however, futile to propose to the farmer that he should use chemicals which would destroy the manurial value of that which 